\title{
Lithosphere dynamics and sedimentary basins: the Arabian plate and analogues
}

\author{
François Roure • Magdalena Scheck-Wenderoth • \\ Abdullah Gahnoog • Tim Pharaoh
}

Published online: 6 November 2010

(C) Saudi Society for Geosciences 2010

The Task Force on Sedimentary Basins was initiated in 2005 on behalf of the International Lithosphere Programme (ILP), in order to (1) assist the international community of Earth Scientists involved in the study of asthenospheric and deep lithospheric/crustal processes to exchange views with colleagues involved in the study of sedimentary basins, and to promote collaborative projects integrating surface and deep processes for regional case studies, (2) promote yearly international meetings involving colleagues from universities, research institutes as well as the industry, and (3) provide support for young scientists (Ph.D. and post-docs) to participate in the activities of this international network.

This special issue of the Arabian Journal of Geosciences constitutes the Proceedings of the 5th workshop of this ILP task force, which took place between December 6 and 11, 2009, in Abu Dhabi, being hosted by the Ministry of Energy of the Emirates.

\author{
F. Roure $(\triangle)$ \\ IFP Energies Nouvelles, \\ Rueil-Malmaison, France \\ e-mail: Francois.Roure@ifpenergiesnouvelles.fr \\ M. Scheck-Wenderoth \\ GFZ, \\ Potsdam, Germany \\ e-mail: leni@gfz-potsdam.de \\ A. Gahnoog \\ Ministry of Energy, \\ Abu Dhabi, United Arab Emirates \\ e-mail: agabdi@moenr.gov.ae \\ T. Pharaoh \\ British Geological Survey, \\ Keyworth, UK \\ e-mail: tcp@bgs.ac.uk
}

About 170 participants from 20 countries $(60 \%$ from the Middle-East, i.e. Emirates, Saudi Arabia, Oman, Yemen, Iraq, Iran, Syria, Jordan, and Kuwait, $40 \%$ from EuropeFrance, Germany, The Netherlands, UK, Sweden, Norway, Poland-, Canada, USA, Egypt, and Japan, with 30\% from national research institutes, 30\% from universities, and 30\% from industry) attended the 2.5 days of conference. Fifty oral contributions and 23 posters were presented during this conference, which comprised ten sessions dedicated to the "Geodynamics, paleogeography and tectonic evolution of the Arabian plate and its surroundings", "Lithosphere dynamics and crustal architecture of the Zagros Mountains and Oman Range", "Lithosphere dynamics of intracratonic basins", "Geodynamic and petroleum framework of Saudi Arabia", "Vertical motion, basin formation and deformation in Europe and Black Sea area", "Stress and strain", "Basin development and sedimentary infill in the UAE and adjacent countries", "Regional fluid transfers and dolomitization diagenesis", "Source rocks, thermicity and petroleum modelling", and "Continental crust, 3D lithosphere models and ophiolites". One pre-conference field trip was also organized by colleagues from the UAE University to Al Ain and its vicinity (Fowler et al. 2009) whereas the BGS team guided the post-conference field trip to Dibba (Ellison et al. 2009).

After peer review, 11 manuscripts have been accepted for publication in this special issue, which is published just 1 year after the conference.

The seven first papers focus on various aspects of the geology of the United Arab Emirates:

In his contribution, Ken Glennie provides a comprehensive introduction to the geology and stratigraphic development of the UAE in the context of the Arabian plate. It his followed by two papers resulting from extensive field work in the Oman Range, i.e. a paper by Fontana et al., which describes the lithostratigraphy, sedimentology and diagen- 
esis of Permo-Triassic (Khuff equivalent) carbonate outcrops of the Northern Emirates, and a paper by Warrak, which provides key information on the post-nappe stratigraphy and structural style of the Hatta Zone.

The four next papers present some results of the work performed by BGS and IFP Energies Nouvelles in the Northern Emirates, on behalf of the Ministry of Energy of the Emirates:

In their contribution, Tarapoanca et al. describe in detail the architecture of a regional transect and provide a new structural scenario for the evolution of the Emirati foothills, based on the interpretation of deep seismic profiles recorded by Western-Geco, new Apatite Fission Track data and forward Thrustpack kinematic modelling. Using the result sections of this 2D Thrustpack modelling as input data for further Ceres 2D modelling, Callot et al. present numerous petrographic evidences for diagenesis of Cretaceous platform carbonates operating in an open system, and compare these paleo-fluid signatures with incremental fluid flow reconstructions. In another paper based on extensive field survey and mapping, Goodenough et al. describe very accurately the petrography of the Semail Ophiolite in the Northern Emirates, and propose new scenarii for its magmatic history. Ultimately, Naville et al. document the architecture of the sole thrust of the Semail Ophiolite and its overall unroofing history and residual thickness, based on surface geology, Apatite Fission Track data from plagiogranites, as well as new reflection and refraction data.

The four last papers deal to geodynamic modelling and discuss the evolution of rift basins and passive margins:

In their manuscript, Elesin et al. describe a new geodynamic code, Samovar, which takes into account the rheology of the lower crust. They have applied this code to simulate the evolution of the Baikal rift, suggesting a complete decoupling between the brittle deformation operating in the upper crust, and the regional thinning of the infracontinental mantle, due to a lateral flow of the intervening lower crustal material. Based on new field work in the serpentinite mélanges and ophiolites of the Kermansha area, in the Zagros Mountains, Wrobel-Daveau et al. describe new evidence for mantle exhumation during the early stages of the evolution of the Arabian margin of the Tethyan Ocean.

In the two last papers dedicated to the geology of Yemen, As-Saruri provides a comprehensive description of the sedimentary basins of this country, whereas Khanbari and Huchon focus on the paleostress reconstruction of its volcanic margins.

1- Ken W. Glennie, Structural and stratigraphic development of Abu Dhabi in the context of Arabia.

2- Simone Fontana, Fadi H. Nader, Sadoon Morad, Andrea Ceriani and Ishan S. Al-Aasm, Diagenesis of the Khuff Formation (Permian-Triassic), northern United Arab Emirates.

3- Mohammed Warrak, Forced folding of the neoautochthonous Late Cretaceous-Early Tertiary sequence at the western end of the Hatta Zone, Northern Oman Mountains.

4- Mihai Tarapoanca, Paul Andriessen, Karine Broto, Louis Chérel, Nadine Ellouz-Zimmermann, Jean-Luc Faure, Anne Jardin, Charles Naville and François Roure, Forward kinematic modelling of a regional transect in the Northern Emirates, using geological and apatite fission track age constraints on paleo-burial history.

5- Jean-Paul Callot, Liesbeth Breesch, Nicole Guilhaumou, François Roure, Rudy Swennen and Nadège Vilasi, Paleofluids characterization and fluid flow modelling along a regional transect in Northern United Arabab Emirates (UAE).

6- Kathryn Goodenough, Mike T. Styles, D.I. Schofield, R.J. Thomas, Q.G. Crowley, R.M. Lilly, J. McKervey, D. Stephenson and J. Carney, Architecture of the Oman-UAE Ophiolite: evidence for a multi-phase magmatic history.

7- Charles Naville, Martine Ancel, Paul Andriessen, Patrice Ricarte and François Roure, New constraints on the thickness of the Semail Ophiolite in the Northern Emirates.

8- Yuri Elesin, T. Gerya, Irina M. Artemieva and Hans Thybo, Samovar: a thermo-mechanical code for modeling of geodynamic processes in the lithosphere-application to basin evolution.

9- Jean-Christophe Wrobel-Daveau, Jean-Claude Ringenbach, Saeid Tavakoli, Geoffrey M.H. Ruiz, Pierre Masse and Dominique Frizon de Lamotte, Evidence for mantle exhumation along the Arabian margin in the Zagros (Kermansha area, Iran).

10- Mustafa Abdullatif As-Saruri, Sedimentary basins of Yemen: their tectonic development and lithostratigraphic cover.

11- Khaled Khanbari and Philippe Huchon, Paleostress analysis of the volcanic margins of Yemen.

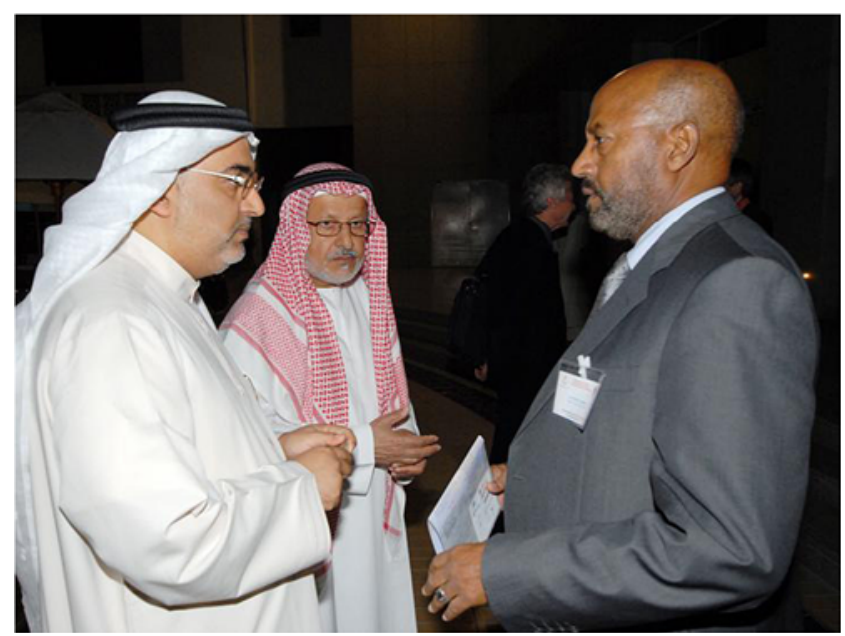

From left to right: Khalid Al Hosani, deputy director, Saleh Al Mahmoudi, director, and Abdullah Gahnoog, scientific advisor, Ministry of Energy, Abu Dhabi 


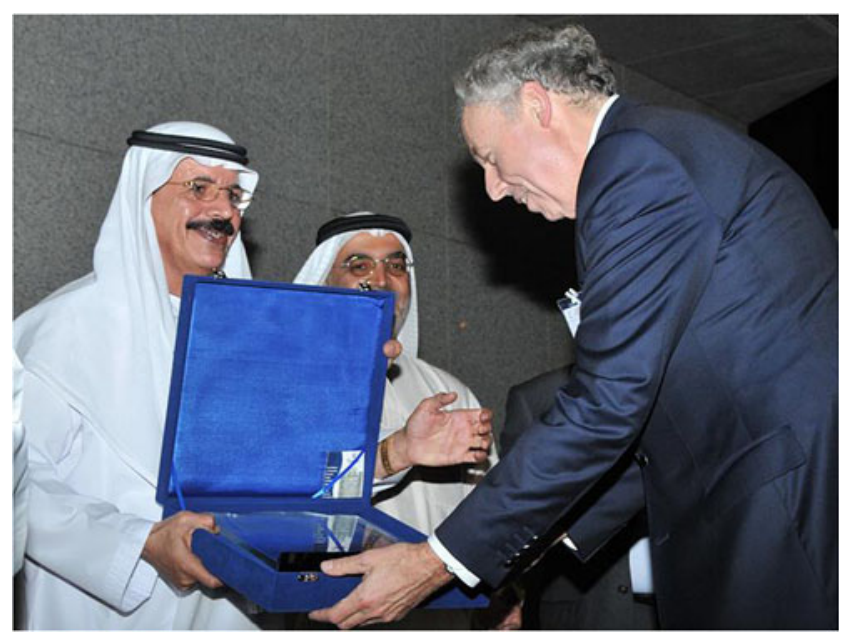

From left to right: Awad Al Otaiba, advisor of the Minister, Khalid Al Hosani, deputy director, and Sierd Cloetingh, president of the International Lithosphere Programme

Acknowledgements ILP express its warmest thanks to H.E. Nasser Mohamed Al Sharhan, Saleh Al Mahmoudi, and Khalid Al Hosani from the Ministry of Energy, for hosting this 5th Workshop of the ILP Task Force on Sedimentary Basins in the Royal Meridien Hotel in Abu Dhabi. ADCO (Abu Dhabi Company for Onshore oil exploration), ADMA-OPCO, BGS, Emarat, Exxon-Mobil, IFP
Energies Nouvelles, NDC, Schlumberger, the United Arab Emirates University (university of Al Ain) and ZADCO (Zakum Development Company) provided also direct support to the conference. We would like also to thank Richard Ellison (BGS), Christoph Lehmann (ADMA-OPCO), Heshan Shebl (ZADCO and Emirati Society of Geosciences), Abdulla Al Mansoori (ADCO), A. Aldahan and Osman Abdelghany (UAE university), Stephen Lokier (PI), and other colleagues from the local companies who provided guidance and assistance during the field trips. Also, the many colleagues and Earth scientists who contributed to the peer review of the manuscripts submitted to this special issue of the AJGS are acknowledged for their efforts and support.

\section{References}

Ellison RA, Phillips ER, Styles MT (2009) A geotraverse across the late Cretaceous fold-and-thrust belt of the UAE: from ophiolite to platform margin. Post-conference field trip, Guide for Dibba zone field excursion, 5th workshop of the ILP Task Force on Sedimentary Basins, 10-11 December 2009, Ministry of Energy of the UAE. pp. 31

Fowler AR, Abdelghany O, Abu Saima M, Ellison R, Kandeel H (2009) Carbonate sedimentology, stratigraphy and structures of the Tertiary foreland basin, Al Ain area, UAE. Pre-conference field trip, 5th workshop of the ILP Task Force on Sedimentary Basins, 6 December 2009, Ministry of Energy of the UAE. pp. 16 